\title{
5 - Uma questão de patos
}

\author{
Benedito Antunes
}

\section{SciELO Books / SciELO Livros / SciELO Libros}

ANTUNES, B. Uma questão de patos. In: A literatura juvenil na escola [online]. São Paulo: Editora Unesp Digita 1, 2019, pp. 77-86. ISBN: 978-859546-331-8. https://doi.org/10.7476/9788595463318.0006.

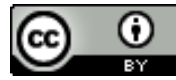

All the contents of this work, except where otherwise noted, is licensed under a Creative Commons Attribution 4.0 International license.

Todo o conteúdo deste trabalho, exceto quando houver ressalva, é publicado sob a licença Creative Commons Atribição 4.0.

Todo el contenido de esta obra, excepto donde se indique lo contrario, está bajo licencia de la licencia Creative Commons Reconocimento 4.0. 


\section{5 \\ UMA QUESTÃO DE PATOS ${ }^{1}$}

Em alguns casos, a melhor maneira de se avaliar uma obra literária é compará-la a outra. Mesmo que de modo aleatório, colocar lado a lado dois livros que, por algum motivo, possam ser aproximados permite iluminar aspectos estruturais e do contexto histórico de um e de outro e até mesmo refletir sobre questões teóricas mais amplas.

Partindo desse pressuposto, proponho-me estabelecer uma comparação entre o romance $O$ apanhador no campo de centeio, do escritor norte-americano Jerome David Salinger, publicado em 1951 (traduzido no Brasil em 1965), e a "novela de texto e imagens" Antes que o mundo acabe, do brasileiro Marcelo Carneiro da Cunha, publicada em 2000. Embora sejam dois livros de estilos e épocas muito diferentes, eles têm em comum o drama existencial vivido por personagens adolescentes num determinado momento de suas vidas. Da perspectiva da recepção, pode-se considerar também que é comum aos dois o próprio público imaginado ou constituído historicamente: o jovem. Essas semelhanças acabam instaurando outros pontos de

1 Este texto foi publicado, com o título "Uma questão de patos: relações entre O apanhador no campo de centeio e Antes que o mundo acabe”, em Aguiar, 2006, p.15-26. 
contato entre eles. E é isso que pretendo indicar brevemente, procurando sugerir algumas questões relacionadas a aspectos temáticos e formais das duas obras.

Acrescento ainda que estudar os dois livros a partir de aspectos comuns, o que acaba criando uma identidade entre eles, pode resultar numa contribuição para a discussão do caráter da literatura juvenil brasileira. A principal desvantagem da comparação aqui proposta é que um dos livros é clássico. Ana Maria Machado (2002, p.109) declara a propósito de O apanhador no campo de centeio: "É um dos melhores livros que já li". O outro é um lançamento recente, que poderá simplesmente desaparecer. Mas justamente aí reside o interesse. Penso que a comparação acabará sendo positiva ao submeter o mais recente a um enfrentamento literário com o clássico, verificando como os mesmos motivos funcionam num e noutro do ponto de vista literário.

Em decorrência, talvez, do próprio drama vivido por suas personagens centrais, nos dois livros pode ser observada uma alternância entre momentos mais tensos do enredo e outros mais suaves e reflexivos, quando a tensão tende a desaparecer para ficar apenas latente. Um desses momentos é representado por uma cena que, com poucas mudanças, aparece tanto em $O$ apanhador no campo de centeio quanto em Antes que o mundo acabe, quando a personagem principal, em uma situação de conflito pessoal e existencial, dirige-se a uma praça ou parque e se ocupa, entre outras coisas, dos patos que ali vivem: Holden Caulfield, enquanto perambula pela fria Nova York de dezembro, à espera do dia adequado para voltar para casa após ser expulso do colégio em que estudava, pergunta-se o que acontece com os patos que vivem no lago do Central Park quando a água está congelada; Daniel, ao sair de casa para refletir sobre um conflito familiar, vai até um parque de Porto Alegre e começa a atirar pedras num lago povoado por patos.

Antes de passar à análise das cenas, é preciso situar brevemente os dois livros. $O$ apanhador no campo de centeio, como se sabe, narra a vida de Holden Caulfield durante dois dias após sua expulsão do Colégio Pencey, na Pensylvânia. Expulso, parte para Nova York no 
sábado à noite, mas pretende se apresentar em casa apenas na quarta-feira, data prevista para o início das férias de Natal. É a terceira vez que ele é expulso de um colégio e por isso não quer enfrentar os pais antes que estes recebam a comunicação oficial da escola. O romance é narrado numa espécie de fluxo de consciência, em que as ações da personagem são mínimas, prevalecendo a manifestação de toda a sua repulsa a um mundo falso e hipócrita. Aliás, a palavra "phoniness" é recorrente no texto original, tendo-se tornado uma espécie de emblema de sua visão do mundo adulto que o cercava.

A personagem conta sua história enquanto se recupera de um esgotamento nervoso em uma clínica psiquiátrica. A narrativa destaca-se sobretudo pelo seu discurso, já que suas ações são quase todas inconclusas. Desse ponto de vista, vale a pena notar sua linguagem, baseada na gíria jovem da época. É por meio dela que se contrapõe a um mundo em que nada se salva, a não ser as crianças, que são inocentes e ainda fora da hipocrisia adulta. Tanto que o título, baseado na canção Comin' Thro' the Rye, de Robert Burns, comporta uma defesa da inocência das crianças perante o mundo adulto. Em sua fantasia, o protagonista pretende ser o apanhador no campo de centeio:

[...] fico imaginando uma porção de garotinhos brincando de alguma coisa num baita campo de centeio e tudo. Milhares de garotinhos, e ninguém por perto - quer dizer, ninguém grande - a não ser eu. E eu fico na beirada de um precipício maluco. Sabe o quê eu tenho de fazer? Tenho que agarrar todo mundo que vai cair ao abismo. Quer dizer, se um deles começar a correr sem olhar onde está indo, eu tenho que aparecer de algum canto e agarrar o garoto. Só isso que eu ia fazer o dia todo. Ia ser o apanhador no campo de centeio e tudo. Sei que é maluquice, mas é a única coisa que eu queria fazer. Sei que é maluquice. (Salinger, 1965, p.147)

A canção diz "Se alguém encontra alguém" e sugere conotações de encontro sexual. Logo, a proteção de Holden aos garotinhos tem como finalidade mantê-los na sua inocência, para que não caiam no 
abismo. Ou seja, para que não se tornem adultos. Temos, assim, um dos temas centrais do livro, que é a dramática passagem da adolescência para a vida adulta.

Antes que o mundo acabe é a história de Daniel, adolescente que vive com a mãe e o padrasto. Não conheceu o pai natural. Há um cruzamento da história de um amigo, suspeito de ter roubado equipamentos do laboratório do colégio, com o início da correspondência com o pai verdadeiro, que é fotógrafo e vive fora do Brasil. $\mathrm{O}$ aparecimento do pai tantos anos depois provoca um começo de crise familiar que vai sendo administrada pelo jovem com a ajuda de Antônio, o padrasto. A amizade com o pai vai-se consolidando por meio da troca de experiências e principalmente de fotografias entre eles. $\mathrm{O}$ pai participa de um projeto que pretende preservar a memória visual dos diferentes povos antes que a padronização mundial acabe com as diferenças.

Ao contrário do livro de Salinger, aqui o clima é de certa harmonia. Os conflitos vividos pela personagem são instaurados numa estrutura equilibrada, bem resolvida e, no fundo, sem conflitos, uma vez que o pai é legal, a mãe é max, o filho é crítico, inteligente, sensível, consciente e compreensivo. Dessa forma, o conjunto do livro configura a passagem do jovem para a idade adulta, que culmina com seu engajamento no projeto do pai, de quem se torna amigo.

A linguagem do livro também é atual e cheia de expressões próprias dos jovens. Além disso, há uma série de referências a aspectos materiais do mundo moderno, como a informática e outros ícones. Da mesma forma, vários temas contemporâneos são abordados, como emancipação da mulher, separação conjugal, drogas, sexo, música, ecologia, adoção etc. $\mathrm{O}$ contato com o pai predispõe o protagonista para a compreensão dos problemas políticos e econômicos internacionais.

Passemos, então, às cenas que se referem aos lagos. No livro de Salinger, ela é mencionada três vezes antes de Caulfield vivê-la. Logo no Capítulo 2, enquanto se despede do professor de História do Colégio Pencey, o velho Spencer: 
Mas o gozado é que, enquanto ia metendo a conversa mole, eu estava pensando no laguinho do Central Park, aquele que fica lá pro lado sul. Imaginava se ele estaria gelado quando eu voltasse para casa e, se estivesse, para onde teriam ido os patos. Estava pensando para onde iam os patos quando o lago ficava todo gelado, se alguém ia lá com um caminhão e os levava para um jardim zoológico ou coisa que o valha, ou se eles simplesmente iam embora voando. (ibidem, p.16)

A segunda menção aparece no Capítulo 9, quando chega a Nova York e toma um táxi para o hotel.

Aí me lembrei duma coisa, de repente:

- Escuta aqui, você sabe onde ficam aqueles patos que vivem no lago lá pro lado sul do Parque? Aquele laguinho? Você sabe por acaso para onde eles vão, os patos, quando fica tudo congelado? Será que você tem uma ideia?

Calculei que era uma chance num milhão. Ele se virou para trás e me olhou como se eu fosse maluco.

- Quê que há, ô meu, tá querendo me gozar?

- Não, só que eu estava interessado em saber. Só isso. (ibidem, p.56)

No Capítulo 12, em outro táxi, o diálogo com o motorista é mais longo e significativo:

O nome dele era Horwitz. Era um sujeito muito mais simpático do que o outro motorista com quem eu tinha andado antes. Seja como for, pensei que ele talvez soubesse alguma coisa sobre os patos.

- Êi, Horwitz. Você conhece aquele laguinho no Central Park? Aquele lá pro lado sul?

- Conheço o quê?

- O laguinho. Aquele lago pequeno que tem lá. Sabe qual é, onde ficam os patos...

- Sei, mas quê que tem? 
- Bom, sabe aqueles patos que ficam nadando nele? Na primavera e tudo? Será que por acaso você sabe pra onde eles vão no inverno?

- Pra onde vai quem?

- Os patos. Será que você sabe, por um acaso? Será que alguém vai lá num caminhão ou sei lá o quê, e leva eles embora, ou será que eles voam sozinhos, pro sul ou coisa que o valha?

$\mathrm{O}$ tal do Horwitz virou para trás e me olhou. Era um sujeito do tipo impaciente pra burro. Mas não era má pessoa.

- Como é que eu vou saber? Como é que eu vou saber um negócio idiota desses, pomba?

$[\ldots]$

- Os peixes não vão pra lugar nenhum. Ficam lá mesmo onde estão, os peixes. Na droga do lago mesmo.

- Com os peixes é diferente. Aí são outros quinhentos. Tou falando dos patos.

- O quê que é diferente com eles? Não vejo nada de diferente - ele respondeu. [...] É muito pior pros peixes, no inverno e tudo, do que pros patos, não vê logo? Use a cabeça, pôxa!

[...]

O sujeito estava tão excitado e tudo que pensei que ele ia se arrebentar em cima dum poste ou coisa parecida.

-Vivem ali mesmo, pomba... Quê que há contigo? O corpo deles retira a nutrição e tudo da droga das algas e da merda toda que tem no gelo. Eles ficam com os poros abertos o tempo todo. São assim mesmo por natureza. Tá entendendo agora? - ele falou, e virou outra vez no banco para me olhar. (ibidem, p.73-4)

Finalmente, no Capítulo 20, depois de se embriagar num bar, Holden começou a caminhar em direção ao parque:

Me lembrei de ir até o laguinho e ver que diabo os patos estavam fazendo, se continuavam por ali. Ainda não sabia se eles ficavam por lá ou não. 
Moro em Nova York desde que nasci e reconheço o Central Park como a palma da minha mão, porque, quando eu era garoto, costumava ir muito lá andar de patins ou de bicicleta. Mas tive um trabalhão danado para encontrar o laguinho naquela noite. Sabia exatamente onde ele ficava - bem pertinho do Central Park Sul e tudo - mas mesmo assim não conseguia encontrar o desgraçado. Eu devia estar mais bêbado do que pensava. Andei pra cá e pra lá, e o lugar ia ficando cada vez mais escuro e mais soturno. Não encontrei vivalma durante o tempo todo que fiquei no parque. Antes assim, porque se desse de cara com alguém provavelmente teria levado o maior susto. Aí, finalmente, achei o lago. Estava metade congelado e metade não. Mas não vi nenhum pato por ali. Dei a volta na droga toda do lago - aliás, quase caí dentro dele uma vez - mas não consegui ver um único pato. Achei que, se houvesse algum por ali, devia estar dormindo ou coisa parecida, bem pertinho da margem ou no gramado. Foi aí que quase caí dentro d'água. Mas não encontrei nenhum. (ibidem, p.131-2)

Em Antes que o mundo acabe, a cena é apenas uma:

E não queria mesmo, não queria olhar para aquele envelope, só joguei ele em cima da mesa e saí de casa, porque se eu ficasse lá, nem sei, acho que ia ter um negócio, chorar, gritar com as pessoas, fazer um escândalo. Hoje, pensando na coisa, eu sei que foi meio exagerado, mas foi a hora, sabem como é, eu não consegui fazer nada melhor. Azar. Saí dali e fui embora, pra qualquer lugar.

Eu vi que tinha passado um tempo porque comecei a sentir frio. A tarde toda já tinha passado e já estava ficando escuro. Eu estava no lugar que eu sempre vou, quando bate uma crise ou coisa assim. No parque, junto do lago. O parque nem fica perto da minha casa, mas é o parque onde eu ia quando era pequeno e eu gosto mais dele do que todos os outros. Essas coisas. Eu estava sentado e atirando pedras no lago, o que é até proibido. Eles têm patos no lago, e eu podia acertar uma pedra em um pato e acabar preso. Aqui na cidade é assim, o pessoal leva esse negócio de ecologia super a sério. Mas eu tava tão 
abalado que até ir preso podia ser uma boa ideia. Comecei a procurar um pato. (Cunha, 2000, p.14)

Em Salinger, a questão dos patos é uma espécie de leitmotiv que percorre todo o livro, pontuando os momentos mais angustiantes vividos por Holden Caulfield. E por isso o motivo adquire um caráter simbólico, de diversos níveis. A misteriosa perseverança dos patos em uma situação inóspita permite a Holden compreender sua própria situação. Além disso, os patos provam que alguns desaparecimentos são apenas temporários. Os patos sempre desaparecem no inverno, mas retornam na primavera, simbolizando que a mudança não é permanente, mas cíclica. Há ainda a possibilidade de se ler o próprio lago como uma metáfora do mundo tal como o vê Holden, porque ele está em parte congelado e em parte não. Funciona, assim, como uma espécie de transição entre dois estados, da mesma forma que Holden se encontra em transição entre a infância e a maioridade.

No caso de Antes que o mundo acabe, o lago tem menos importância. Figura como um refúgio de Daniel nos momentos de crise. Nesse dia, enquanto procura espairecer, ele começa atirar pedras na água. Vem logo a recordação de que isso é proibido por causa da questão ecológica. Aí toma uma decisão que parece um desabafo: estava tão abalado que começou a procurar um pato para acertar e ir preso. Nada disso é muito convincente, predominando mesmo a preocupação com a questão ecológica, que inclusive será retomada em outras passagens.

Aqui é preciso recordar que o livro não esconde sua estrutura um tanto pedagógica: quer mesmo fazer a cabeça do leitor, quer convencê-lo do politicamente correto. Isso está explicitado já no paratexto do livro, indicando que ele tem como proposta interagir com o leitor, que deveria aprender a olhar o mundo pela fotografia. Inclusive contém instruções para o leitor fotografar melhor e traz uma peça destacável dotada de um retângulo para sugerir o enquadramento proporcionado pela fotografia. Dessa forma, o livro acaba adquirindo uma estrutura complexa, que passa da comunicação epistolar e fotográfica entre pai e filho para a comunicação multimídia entre o 
narrador (ou autor implícito, talvez) e o leitor, sobre quem se quer, explicitamente, agir. É, nesse sentido, pedagógico, mas sem cair, talvez, num didatismo fácil pela diversidade de material e de perspectivas apresentadas à fruição do receptor. Ao fim, Daniel vira fotógrafo e se engaja no projeto do pai, de quem recebe máquina fotográfica, apetrechos e companhia para viajar.

Holden também é sensível, inteligente e escritor. Aliás, na escola só não leva bomba em Inglês, pela qualidade de sua redação. Ele também se dirige a seus leitores e, com isso, pretende convencê-los de algo. A diferença parece situar-se na estrutura. Holden é desbocado e negativo. Não acredita em quase nada. Pode-se dizer que, no pós-guerra, parece constituir uma voz que vai desembocar nos movimentos jovens de contestação dos anos 1950 e 1960. Até mesmo nos cuidados com que ele é trazido de volta à normalidade da vida, ajustado a seu ritmo e convenções, parece antecipar o que acontece com os hippies.

A mãe de Daniel, por outro lado, teve uma fase meio hippie. $\mathrm{O}$ pai, certamente na mesma fase, partiu para outra, até se aproveitando da liberdade sexual que se pregava. Seu engajamento agora é na luta contra a globalização. Seu projeto visa registrar o mundo como ele é antes que acabe. Contrapõe-se, com isso, o processo de globalização às culturas regionais, nacionais. Dessa forma, a vinculação dos pais de Daniel ao movimento hippie cria uma linha anticapitalista, de contestação, que desemboca numa espécie de movimento contrário à globalização. Assim, perpassa o livro certo tom saudosista, que lamenta as mudanças decorrentes do progresso tecnológico, como aliás se sugere no próprio título.

Seria necessário aprofundar essas questões para avaliar se o livro tem perspectiva conservadora ou consegue problematizar de forma dialética aspectos sociais e econômicos do mundo contemporâneo. Mas uma coisa parece certa: a angústia do jovem dos anos 1950 configurada em $O$ apanhador no campo de centeio deu lugar a uma preocupação existencial mais controlada em Antes que o mundo acabe. Se houve maior integração do jovem a esse novo contexto social, com todo o possível conformismo daí advindo, ou se o jovem do final 
do século se beneficiou do enfrentamento traumático das contradições sociais pelos seus antepassados é uma questão aberta. ${ }^{2}$ Os dois livros, no entanto, representam essa diversidade de questões. E sua qualidade literária talvez esteja atrelada a essa condição.

Finalizando, cabe fazer algumas considerações sobre o público a que se destinam os livros. O primeiro tornou-se um clássico, apreciado sobretudo pelos jovens. Mas é pouco provável que tenha sido escrito com essa finalidade. Basta observar a história misteriosa de seu autor, que parece ter incorporado a personalidade de Holden. Já o livro brasileiro tem como alvo claro o público jovem, sendo caracterizado em vários aspectos como literatura juvenil. Que diferenças separariam um do outro? Trata-se também de uma questão que merece um aprofundamento. A título de hipótese de trabalho, adiantaria que o caminho está na análise de sua própria forma. Ao instaurar conflitos numa estrutura equilibrada e não conflituosa, representada pelo universo em que vive Daniel, o livro de Marcelo Carneiro da Cunha configura a sobreposição de uma espécie de autor implícito, que controla e quer preservar o mundo antes que ele acabe, a um narrador-aprendiz, que não tem dificuldades para se adaptar à consciência e ao projeto do outro. No livro americano, ainda que no fundo haja uma perspectiva semelhante, a fratura não aparece, pois o narrador desajustado e meio maluquinho encobre perfeitamente, pela linguagem, a possível consciência do autor implícito. Em última instância, certa consciência pedagógica estaria fechando o livro brasileiro, caracterizado como juvenil, enquanto a ruminação inconformista permite uma abertura a uma diversidade maior de leituras no livro americano. Ainda aqui, porém, é possível admitir que a representação das diferentes visões de mundo encontra sua forma adequada nos dois livros.

2 Uma abordagem aprofundada do livro foi feita por Maria Alice Faria no ensaio "O literário e o pedagógico no fio da navalha" (2008). 